ISSN: 2146-3042

DOI: $10.25095 /$ mufad.625752

\title{
Maliyet Bilgileri Temelinde Fiyatlama Kararları İçin Stratejik Pazarlama Muhasebesi: X Otel İşletmesinde Bir Uygulama
}

Mehmet GÜNER*

Ersin KURNAZ**

\section{$\ddot{O Z Z E T}$}

Bu çalışmada, Erzincan'da hizmet sektöründe faaliyet gösteren dört yıldızlı bir otel işletmesinde stratejik pazarlama muhasebesi uygulanarak, gelecek döneme ait en uygun fiyatlama politikasinin ortaya konulması amaçlanmaktadır. Bu amaç doğrultusunda ilk olarak kavramsal çerçeve başlı̆̆ altında pazarlama bilgi sistemi, muhasebe bilgi sistemi ve bu iki sistem arasındaki iliş̧i sonucu ortaya çıkan stratejik pazarlama muhasebesi ele alınmıştır.Uygulama bölümünde ise, Erzincan'daki dört yıldızlı bir otelin geçmiş yıl maliyet verileri kullanılarak maliyet-hacim-kar analizi yapılmıştır. Sonuç olarak, işletmenin gelecek yll hedeflediği kara ulaşabilmesi için belirlemesi gereken en uygun fiyat tespit edilmiştir.

Anahtar Kelimeler: Pazarlama Bilgi Sistemi, Muhasebe Bilgi Sistemi, Stratejik Pazarlama Muhasebesi.

JEL Sinıflandırması: M31, M40.

\section{Strategic Marketing Accounting for Pricing Decisions Based on Cost Information:} An Application On X Hotel Business

\section{ABSTRACT}

In this study, strategic marketing accounting is applied in a four-star hotel operating in service sector in Erzincan and it is aimed to present the most appropriate pricing policy for the future period. For this purpose, firstly, under the title of conceptual framework, marketing information system, accounting information system and strategic marketing accounting resulting from the relationship between these two systems are discussed. In the application section, cost-volume-profitanalysis was made using the previous year cost data of a four-star hotel in Erzincan. As a result, the most favorable price was determined for the enterprise to reach the target profit in the next year.

Keywords: Marketing Information System, Accounting Information System, Strategic Marketing Accounting.

Jel Classification: M31, M40.

Makale Gönderim Tarihi: 11.02.2019

Makale Kabul Tarihi: 08.06.2019

Makale Türü: Örnek Olay Vaka Analizi

\footnotetext{
* Dr. Öğr. Üyesi,Erzincan Binali Yıldırım Üniversitesi, İktisadi ve İdari Bilimler Fakültesi, mehmetguner@gmail.com, Orcid ID: 0000-0002-9523-1519.

** Sorumlu Yazar, Dr. Öğr. Üyesi, Erzincan Binali Yıldırım Üniversitesi, İktisadi ve İdari Bilimler Fakültesi, ersinkurnaz2429@gmail.com, Orcid ID:0000-0002-6787-5368.
} 


\section{GİRiş}

İşletmeler her geçen gün belirsizliğin arttığı, rekabet edilebilirliğin zorlaştığı ve süreçlerin giderek daha karmaşık bir hal aldığı iş dünyasında faaliyetlerini sürdürmektedir. Giderek zorlaşan bu koşullar altında işletmelerin ayakta kalabilmesi ancak ileriye dönük olarak alacakları pazarlama kararları, fiyatlandırma politikası ve maliyetlerin yönetimi gibi stratejik öneme sahip kararların etkinliğine ve verimliliğine bağlıdır. Stratejik karar alma sürecinde işletme bilgi sisteminin alt sistemleri olan Pazarlama Bilgi Sistemi (PBS)ve Muhasebe Bilgi Sisteminin (MBS)temel işlevleri ve birbiriyle olan etkileşimleri oldukça önemlidir. Çünkü, bu iki sistemden elde edilen veriler işletmenin geleceğe yönelik stratejisini belirlemede, doğru ve güvenilir kararlar almada temel oluşturmaktadır. Gelecek dönem mal ve hizmetler için en uygun fiyatlandırma kararlarının alınabilmesinde, MBS'den sağlanan geçmiş dönem maliyet bilgilerinden yararlanılacaktır. Bu durum PBS ile MBS arasındaki ilişkiyi ve kesiştikleri noktayı açıkça ortaya koymaktadır. Genel olarak PBS ile MBS'nin kesiştiği alanlar, işletmelerde mal üretimi ve hizmet sunumunun planlanması, fiyatlandırma kararları, tutundurma ve dağıtım gibi politikaların belirlenmesi ve pazarlama yatırım analizlerinin yapılması şeklinde sıralanabilir. Her iki sistemin kesiştiği bu alanlar da Stratejik Pazarlama Muhasebesini (SPM) ortaya çıkarmıştır.Genel olarak, SPM, işletmenin pazarlama ve satış faaliyetlerinin analizi üzerine yoğunlaşan, stratejik pazarlamanın görev ve sorumluluk alanlarında ortaya çıkan, stratejik pazarlama kararlarına ilişkin ihtiyaç duyulan önemli bilgileri karşılamayı ön plana çıkaran muhasebe olarak açıklanabilir.

Bu çalışma ile Erzincan'da hizmet sektöründe faaliyet gösteren 4 yıldızlı bir otel işletmesinde SPMaraçları kullanılarak 2019 yılı fiyatlandırma tahminlerinin yapılması amaçlanmaktadır. Bu amaç doğrultusunda ilk olarak kavramsal çerçeve başlığı altında PBS, MBSve bu iki sistem arasındaki ilişki sonucu ortaya çıkan SPMele alınmıştır. Daha sonra ise, SPMaçısından Erzincan'da faaliyet gösteren 4 yıldızlı bir otel işletmesinde mevcut faaliyet dönemi ve ekonomik koşullar göz önünde bulundurularak çeşitli analiz yöntemleri ile otelin gelecek dönemde amaçladığ 1 kar tutarına ulaşabilmesi için en uygun hizmet fiyatı belirlenmiştir.

SPM ile ilgili ilgili literatür incelendiğinde, yapılmış çalışmaların çoğunda konunun teorik olarak ele alındığı gözlemlenmiştir. $\mathrm{Bu}$ çalışmanın, uygulama içermesi dolayısıyla, SPM alanında uygulamalı olarak yapılacak diğer çalışmalara katkı sağlayacağı düşünülmektedir. Ayrıca, uygulama yapılmış olan çalışmalarda, tek tip ürün veya hizmet sunumu yapan işletmelerin ele alındığı, dolayısıyla geleceğe dönük tek bir stratejik fiyat tahmini yapıldığı görülmüştür. $\mathrm{Bu}$ bağlamda, çalışmanın birden fazla hizmet sunan bir işletmede, bu hizmetlerin her biri için stratejik fiyat tahmininde bulunması sebebiyle literatüre katkı sağlayacağı söylenebilir.

\section{KAVRAMSAL ÇERÇEVE}

PBS, pazarlama kararlarına yardımcı olmak için plan ve bir program dâhilinde bilginin toplanması, sınıflandırılması, analiz edilmesi, değerlendirilmesi ve bu bilginin ilgili kişilere istenilen zamanda raporlanması süreci şeklinde tanımlanabilir (Gegez, 2015: 20). PBS, işletmeler için stratejik önem taşıyan bir süreç olup, bu süreç pazarlama konusunda uygun raporların hazırlanması, piyasa açısından geçmiş ve yeni verilerin karşılaştırılarak bilgilerin 
güncellenmesi, ortaya çıkan sonuçların çeşitli yöntemler kullanılarak analiz edilmesi gibi konuları içermektedir (Tolon, 2006: 27).

İşletme yöneticileri işletmenin geleceğiyle ilgili karar almalarında yararlı olacağını düşündükleri bilgileri iç ve dış bilgi kaynaklarından toplayarak, kendileri için en çok yarar sağlayacak olan bilgileri seçerler. Karar alıcıların elde ettikleri bu bilgiler PBS'nin girdilerini oluşturmaktadır. (Tekin, 2006: 222). PBS, işletme içi ve dışı kaynaklardan bilgileri toplama, değerlendirme, düzeltme, saklama, koruma ve ilgili yöneticilere sunmak için sürekli ve düzenli çalışmalar yapmaktadır. Ayrıca işletme için yararlı olacağı düşünülen pazarlama diş çevresi, tüketiciler, fiyatlar, reklam harcamaları, satışlar, rekabet ve dağıtım giderleri gibi bilgilerle de ilgilenmektedir (Mucuk, 2007: 51).

PBS sayesinde tüketicilerin geri bildirimleri ile mal ve hizmetlerdeki etkililiğin, verimliliğin ve ekonomikliliğin artışı sağlanmaktadır. Aynı zamanda söz konusu mal ve hizmetlerin geliştirilmesine veya ortadan kaldırılmasına ilişkin kararların alınması konusunda da PBS'den yararlanılmaktadır. Bu sayede işletmenin rekabet gücünün artırılması mümkün olmaktadir (Li, 1997:27).

MBS ise, işletmenin tüm yönetim fonksiyonlarına yol göstermek amacıyla verileri toplamak, işlemek, depolamak ve yöneticiler ihtiyaç duyduğunda gerekli bilgileri kullanımlarına sunmak üzere oluşturulan bir sistemdir. Belirlenen amaçlara ulaşabilmek için mali karakterdeki işletme faaliyetlerini kaydetme, analiz etme ve yönetime karar vermekte ve sorunların çözümünde yardımcı olma işlevini yerine getiren MBS, para ile ifade edilebilen verileri işleyerek işletme içi ve dışı bilgi kullanıcılarının ihtiyaç duyduğu doğru ve güvenilir bilgileri üretmek amacıyla dönüştüren, ortaya çıkan bilgileri raporlar haline getiren, gerektiği zaman tekrar kullanmak üzere depolayan bir bilgi sistemidir. MBS'nin girdisi mali nitelikli işlemlere ilişkin belgeler, çıktısı ise finansal tablolar ve raporlardır (Doğan, 2016:198).

MBS'nin etkinliği ve verimliliği sistemin sağladığı faydanın maliyetini aştığı durumlar karşılaştırılarak ölçülebilir. Bu sistemin etkinliği; bilginin kapsamı, zamanlaması ve toplanması şeklinde üç temel başlık altında değerlendirilebilir. Bilginin kapsamı ile gelecekteki olayları tahmin etmeye katkı sağlayabilecek finansal ve finansal olmayan iç ve dış bilgiler kabul edilir. Zamanlama kalitesi, MBS'nin kullanıcılarına sistematik raporlar sunarak bilgi ihtiyaçlarını karşılama yeteneği ile ilgilidir. Son olarak bilginin toplanması veya birleştirilmesi ise, belirli bir zaman aralığında elde edilen bilgilerin sınıflandırılarak ve özetlenerek ihtiyaçlar doğrultusunda kullanılması ile ilgilidir (Sajady et.,2008:49).

Pazarlama, üretim, finans, Ar-Ge, halkla ilişkiler ve insan kaynakları gibi bilgi sistemlerinden elde ettikleri verileri, muhasebe sürecinde işletme yöneticilerinin karar verirken kullanacakları bilgiye dönüştüren $\mathrm{MBS}$, işletme yöneticilerine faaliyetlerin yönetilmesine ve kontrolüne ilişkin diğer bilgi sistemlerinden elde edilen bilgilerin sağlanmasında temel bilgi kaynağını oluşturmaktadır (Dinç ve Abdioğlu, 2009: 167-168). Muhasebe bilgileri, amaçların belirlenmesinde, kararların alınmasında ya da gerçekleşen faaliyet ile tahminlerdeki sapmaların değerlendirilmesinde önemli bir kaynaktır (Sevgener ve Hacırüstemoğlu, 2000: 10). Muhasebe bilgileri işletme bilgi sistemleri içerisinde en eski, en önemli ve en kapsamlısı olan MBS tarafından üretilmektedir. MBS tarafından üretilen bu bilgiler, çok sayıdaki işletme içi ve dışı bilgi kullanıcıları tarafından kullanılmaktadır (Acar ve Özçelik, 2011: 11). 
MBS ile tüm yönetim bilgi sistemleri arasında karşılıklı bilgi alışverişi söz konusudur. Ayrıca tüm yönetim sistemlerinin ortasında MBS yer almaktadır. İşletmede üretilen bilgilerin büyük bir kısmı MBS sürecinde değerlendirilerek diğer bilgi sistemlerin kullanabileceği yeni bilgiler üretmektedir. Nitekim MBS bilgileri üretirken diğer sistemlerden de karş1lıklı bilgi alışverişinde bulunmaktadır (Şan, 1996:313).

Pazar araştırma süreci, işletmenin geleceğine yönelik tahminleri ile geçmişe dönük karşılaştırmalarını kapsayan bir süreçtir. Bu kapsamda pazar araştırma sürecinde, hem PBS hem de MBS'den elde edilecek bilgilere ihtiyaç duyulmaktadır. Çünkü yöneticiler pazar araştırmaları sürecinde müşteri tatmin düzeyinin ve ihtiyaçlarının belirlenmesi için gelecek dönem tahminlerinde PBS'den, işletmenin geçmiş dönem performansının analizi, firsatların değerlendirilmesi ve bütçe planlama çalışmalarında ise, MBS'den elde edilen bilgilerden yararlanmaktadır. (Yılmaz ve Demireli, 2013: 298). Fiyatlandırma kararlarının, rekabet koşullarına uygun, müşteri için kabul edilebilir düzeyde olması ve işletme için yeterli kârlılık oranını da dikkate alması gerekmektedir. İşletmeler için bu gibi hayati öneme sahip pazarlama kararları yine MBS tarafından üretilen bilgiler doğrultusunda alınmaktadır. Bu durum iki sistem arasında güçlü bir ilişkinin olduğunu göstermektedir. (Dinçer ve Dinçer, 2005: 354). $\mathrm{Bu}$ iki bilgi sistemi arasındaki ilişkinin, işletme içerisinde etkili, verimli ve koordineli bir şekilde uygulanabilmesi de ancak işletmelerde SPM anlayışının uygulanması ile olabilir.

PBS ile MBS arasındaki ilişki sonucu ortaya çıkan SPM, pazarlama ve muhasebenin kesişim noktasını oluşturan ürün ve hizmet maliyetleri ile fiyatlandırma kararlarında işletme yöneticilerinin dikkate alması gereken bir kavramdır. Çünkü SPM, müşteri faturalarının işlenmesi, satış faaliyetlerine ilişkin bilgilerin toplanması, uygun stok yönetiminin yapılması, ürün ve hizmet maliyetlerinin hesaplanması, uygun fiyatların belirlenmesi gibi birçok konuda yöneticilere stratejik öneme sahip bilgiler veren bir süreçtir (Keller, 1966: 10-11). SPM, hizmetlerin tasarım veya ürünlerin depoya giriş anından, müşterilere ulaştırılıp paraya çevrilinceye kadar geçen zaman zarfında ortaya çıkan maliyet bilgilerinin nelerden oluştuğunu belirleyen ve bunların incelenmesi ve yorumunu yaparak maliyetlerin düşürülmesi ve uygun fiyatların belirlenmesi için yöneticilere önerilerde bulunmayı amaçlayan işlemler bütünü şeklinde tanımlanabilir. SPM'nin odak noktasını maliyet analizleri, maliyet kontrolü, maliyetlerin azaltılması ve uygun fiyatların belirlenmesi gibi konular oluşturmaktadır. Ayrıca pazarlama faaliyetlerinin etkinliği ve verimliliği sağlanarak net kârın arttırılmasında da önemli bir faktör olarak görülmektedir (Akdoğan, 1982: 22-23).

Fiyat politikası, pazarlama ve muhasebenin en önemli ortak noktalarından birisidir. Pazarlamada fiyat politikası, fiyat yönetiminde geniş bir anlayış olarak ortaya çıkmaktadır. Maliyet muhasebesinde ise, uygun bir şekilde en düşük fiyat alt sınırının hesaplanmasıyla yetinilmektedir. İşletmelerde fiyatlar, PBS içinde karar vermeye temel oluşturan maliyet muhasebesinden sağlanan bilgilere dayalı olarak belirlenmektedir (Ceran ve İnal, 2004: 64). Fiyat politikasında karar almada maliyet muhasebesinden elde edilen bilgiler kullanılmaktadır. Ancak fiyat alt sınırını tespit etmede, satış gelirleri ile maliyetler pazarlama faaliyetleri üzerinde etkili olmaktadır (Rese, 2006: 743-744). Fiyat alt sınırı maliyete ve satış gelirine bağlı olarak belirlendiğinden, fiyat politikasında maliyet yüksekliği ve kalite de karar almada belirleyici bir unsurdur (Ceran ve Bezirci, 2011: 109).

İşletmelerde maliyetlerin yeteri kadar ayrıntılı takip edilememesi, fiyatlama kararlarına ilişkin sorunların en önemlisini oluşturmaktadır. $\mathrm{Bu}$ sorunda işletme içinde 
etkinliği belirleyememekte veya düşürmektedir. Fiyatlandırma konusundaki sorunlar işletme yöneticilerini işletmede etkin bir şekilde çalışan PBS'yi ve MBS'yi oluşturmalarını gerekli kılmaktadır. Bu sayede doğru fiyatlandırma kararları ile hem iç hem de dış pazarda uygun fiyatlarla rekabet edilebilecek, satışlar ve karlılık artırılabilecektir (Ceran ve Bezirci, 2011: 109).

PBS ile MBS arasındaki ilişki sonucu ortaya çıkan SPM kapsamında fiyatlandırma kararlarının alınmasında kullanılan birçok finansal teknik ve analiz vardır. Bunlardan en çok kullanılanı Maliyet-Hacim-Kâr analizidir. Maliyet-Hacim-Kâr analizi, işletmelerin gelir faaliyetlerinin maliyetlerini ne şekilde etkilediğini belirlemek için kullanılan bir analizdir. SPM açısından bu analizin uygulanabilmesi için toplam maliyet fonksiyonunun hesaplanması, üretim ve satış hacminin belirlenmesi ve en uygun fiyatın tespit edilmesi aşamalarının sırasıyla yapılması gerekmektedir (Büyükmirza, 2014: 378-390).

\section{LITERATÜR TARAMASI}

Araştırmanın bu kısmında, SPM ile ilgili çalışmalardan bazıları aşağıda incelenmiştir.

Yıldız ve Ceran (2018) çalışmalarında işletme bilgi sisteminin alt sistemleri olan PBS ile MBS arasındaki ilişkiyi ve bu ilişki sonucu ortaya çıkan SPM konusunu ele almışlardır. Araştırmanın uygulama bölümünde, Antalya'nın Manavgat ilçesinde faaliyet gösteren beş yıldızlı bir otel işletmesinin 2017 yılında elde ettiği kâr tutarı ve maliyet verilerinden yararlanılarak otelin 2018 yılı için hedeflediği kâr tutarına ulaşabilmesi için stratejik bir fiyat tespit edilmiştir.

Sümerli Sarıül (2018) araştırmalarında pazarlama muhasebesi ve müşteri kârlılığına yönelik bir literatür taraması ve genel bir değerlendirme yapmayı amaçlamıştır. Bu amaç doğrultusunda, PBS, MBS ve pazarlama muhasebesi ile ilgili genel bilgiler verilerek kapsamlı bir değerlendirmede bulunulmuştur.

Temelli ve Eroğlu Pektaş (2018) çalışmalarında PBS ile MBS'nin kesişme noktasını oluşturan ürün/hizmet maliyetlerini ve ürün/hizmet fiyatlama faaliyetlerini, SPM açısından incelemişlerdir. Bu kapsamda PBS ve MBS ile ilgili bilgilere yer verilerek her iki sistem arasındaki ilişki teorik olarak ele alınmıştır. Son olarak, SPM açıklanarak işletmeler açısından önemi üzerinde durulmuştur.

Gündoğmuş ve Köroğlu (2017) çalışmalarında Marmaris'te faaliyet gösteren dört yıldızlı bir otel işletmesinde SPM'yi uygulayarak, gelecek döneme ait en uygun fiyat politikasını ortaya koymayı amaçlamışlardır. Bu doğrultuda, otelin geçmiş yıl eldeettiği kâr tutarı ve maliyet verilerinden yararlanılmış ve çeşitli maliyet analizleri yapılarak, işletmenin gelecek dönem için hedeflediği kâr tutarına ulaşabilmesi için uygulaması gereken en uygun fiyat tespit edilmiştir.

Ceran ve Özdemir (2013) çalışmalarında sağlık işletmelerinin paket işlem fiyat uygulamasından hem kar hem de müşteri memnuniyeti sağlamak için Hedef Maliyetleme Yöntemi (HMY) ve SPM kavramlarından faydalanarak paket işlem fiyatını aşmayacak şekilde maliyetlerin belirlenmesine yönelik maliyet düşürme çalışmaları konusunu incelemişlerdir. Bu doğrultuda Aksaray'da özel bir diyaliz merkezinde uygulama yapılmıştır. 
Sonuç olarak, sağlı işletmelerinde HMY ve SPM'nin beraber uygulanabileceği ifade edilmiştir.

Kırlı ve diğerleri (2012) SPM konu edindikleri teorik araştırmalarında SPM'yı ortaya çıkaran PBS ve MBS konularını açıklamıştır. Daha sonra ise, stratejik yönetim muhasebesinin önemli bir tamamlayıcısı olarak SPM'yi değerlendirilmiştir.

Ceran ve Bezirci (2011) SPM'yi konu edindikleri çalışmalarında SPM'nin küresel rekabet ortamında bulunan işletmelerin varlıklarını devam ettirebilmeleri ve gerçekleştirmiş oldukları faaliyetlerin sürekliliğini sağlanabilmeleri açısından önemli bir araç olduğunu ifade etmişlerdir.

Badem ve Fırat (2011) temel pazarlama bileşenleri açısından muhasebe verilerinin kullanılmasını, bir diğer ifadeyle, pazarlama muhasebesini konu edindikleri teorik çalışmalarında, işletmenin başarısı için ne tür muhasebe verilerinin kullanılması gerektiği üzerinde durmuşlardır.

Ceran ve İnal (2004) pazarlama ve muhasebe bilimlerinin kesişimi sonucu ortaya çıkan pazarlama muhasebesinin içeriği hakkında temel oluşturmayı amaçladıkları teorik nitelikteki araştırmalarında, pazarlama muhasebesinin tanımı, görev alanları ve konusunu geniş bir şekilde ele almışlardır.

\section{MALIYYT BÍLGILERI TEMELINDE FIYATLAMA KARARLARININ STRATEJIKK PAZARLAMA MUHASEBESİ AÇISINDAN İNCELENMESI}

Çalışmanın bu bölümünde, Erzincan ilinde faaliyet gösteren $\mathrm{X}$ otel işletmesine ait bilgilerden hareketle SPM uygulaması gerçekleştirilerek söz konusu otel işletmesinin amaçlanan kara ulaşmada ortaya koyması gereken fiyatlandırma politikası tespit edilmeye çalışılacaktır.

\subsection{Araştırmanın Amacı}

Bu çalışmada, Erzincan'da hizmet sektöründe faaliyet gösteren 4 yıldızlı bir otel işletmesinde stratejik pazarlama muhasebesi araçları kullanılarak 2019 yılı fiyatlandırma tahminleri yapılması amaçlanmaktadır. Bu amaca ulaşabilmek için;

- İşletmenin toplam gider fonksiyonu belirlenecek,

- $\quad$ İşletmenin satışını yaptığı odaların kara geçiş noktası (satış karışımının başabaş noktasi) tespit edilecek,

- İşletmenin 2018 y1lı kar fonksiyonu ve mevcut verilerden hareketle kar tutarı ortaya konulacak,

- Tahmini enflasyon rakamlarından hareketle 2019 gider projeksiyonu oluşturularak 2019 yılı toplam gider fonksiyonu tahmin edilecek,

- 2019 yılı başabaş noktası belirlenecek,

- 2019 yılı kar fonksiyonu oluşturulacak,

- Amaçlanan kara ulaşabilmek için satılan ürünlerin (odaların) fiyatlarının ne olması gerektiğine karar verilecektir. 


\subsection{Araştırmanın Yöntemi}

Çalışmada örnek olay yönteminden yararlanılmıştır. Örnek olay yöntemi maliyet ve yönetim muhasebesi uygulamalarında sıklıkla başvurulan etkili bir yöntemdir. Fiili verilere dayandığı için güvenilirliği yüksektir. Araştırmada kullanılacak veriler $X$ otel işletmesi muhasebe müdürü ile yapılan görüşmeler ve gözlemler neticesinde elde edilmiştir. Çalışma, $X$ otel işletmesinin 2018 yılı faaliyet verileri kullanılarak şekillendirilmiştir.

\subsection{Otel İşletmesi Hacim ve Gider Verileri}

Verileri kullanılan X otel işletmesi 1994 yılında Erzincan'da faaliyete başlayan ve günümüzde dört yıldızlı olarak hizmete devam eden bir işletmedir. İşletme, 2018 yılını yaklaşık \% 70 doluluk oranı ile tamamlamıştır. Oda-kahvaltı konseptinde faaliyet gösteren işletmede özellikle yaz sezonunda dügün töreni gibi organizasyonlar da yapılmaktadır. Çalışmada, otel karar süreçlerinde asıl faaliyet olarak etkiye sahip olan oda satışları ve bu satışlardan kaynaklanan giderler üzerine odaklanılmış kısıtlı bir zaman aralığında yapılan düğün töreni vb. organizasyonlardan elde edilen gelirler ve katlanılan giderler kapsam dış1 bırakılmıştır.

\subsubsection{Yılı Satışları (Satılan Yatak Sayısı)}

Otelde satışı yapılan üç tip oda bulunmaktadır. Bunlar; single oda, double oda ve süit oda olarak adlandırılmıştır. Ortak bir hacim ölçüsü biriminin ifade edilebilmesi için satılan oda sayısı yerine satılan yatak sayısı verileri üzerinden hareket edilmesinin daha doğru olacağ 1 ve söz konusu odaların ortak birimi ifade edecek şekilde katsayılarla ifade edilmesi gerektiği sonucuna ulaşılmıştır. Otel yetkilileri ile yapılan görüşmeler ve tespitler neticesinde odaların satışa hazır hale getirilmesi için harcanan emek dikkate alındığında single odaların tek yatak olarak, double odaların iki yatak olarak ve süit odaların ise üç yatak olarak katsayılandırılmasının doğru olacağı sonucuna ulaşılmıştır. Bu tespitten hareketle, aylar itibarı ile 2018 yılı yatak satış sayıları Tablo 1'de sunulmuştur.

Tablo 1. Aylar İtibarı ile Yatak Satış Sayıları

\begin{tabular}{|c|c|c|c|c|c|c|c|c|c|c|c|c|c|}
\hline $\begin{array}{l}\text { Oda } \\
\text { Türü }\end{array}$ & 䔍 & $\begin{array}{l}\overrightarrow{\tilde{J}} \\
\stackrel{\vec{Z}}{\tilde{n}}\end{array}$ & $\stackrel{\bar{E}}{\Sigma}$ & $\begin{array}{l}\text { 矛 } \\
\text { 艺 }\end{array}$ & 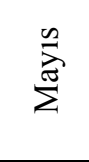 & 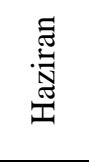 & 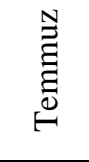 & 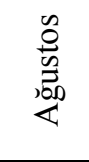 & 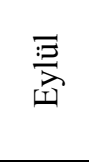 & $\frac{\Xi}{\frac{\Xi}{-}}$ & 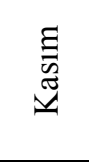 & $\begin{array}{l}\text { 岸 } \\
\text { 苞 }\end{array}$ & $\frac{\tilde{E}}{\underline{\underline{\sigma}}}$ \\
\hline Single & 350 & 338 & 410 & 520 & 650 & 680 & 750 & 785 & 650 & 530 & 420 & 380 & 6463 \\
\hline Double & 380 & 420 & 560 & 700 & 860 & 1060 & 1080 & 1420 & 1160 & 920 & 700 & 540 & 9800 \\
\hline Suit & 6 & 3 & 6 & 9 & 6 & 12 & 12 & 15 & 9 & 6 & 3 & 3 & 90 \\
\hline Toplam & 736 & 761 & 976 & 1229 & 1516 & 1752 & 1842 & 2220 & 1819 & 1456 & 1123 & 923 & 16353 \\
\hline
\end{tabular}

\subsubsection{Yılı Gider Verileri}

Toplam gider fonksiyonunun oluşturulmasında temel teşkil edecek esas unsurlardan birisi de işletmenin gider bilgileridir. Söz konusu işletmenin 2018 dönemi için gerçekleşen giderleri kalemler itibarı ile Tablo 2'de sunulmuştur. 
(84): 113-132

Tablo 2. 2018 Y1lı Gerçekleşen Giderler

\begin{tabular}{|c|c|c|c|c|c|c|c|c|c|c|c|c|c|}
\hline Giderler & Ocak & Şubat & Mart & Nisan & Mayıs & Haziran & Temmuz & Ağustos & Eylül & Ekim & Kasım & Aralık & Toplam \\
\hline Personel Ücreti & 16.878 & 15.119 & 19.381 & 21.343 & 21.690 & 21.419 & 22.125 & 22.352 & 20.350 & 18.439 & 18.930 & 17.627 & 235.653 \\
\hline Yiyecek Gideri & 10.300 & 10.150 & 10.600 & 11.500 & 12.500 & 15.620 & 17.150 & 18.400 & 16.300 & 14.320 & 13.500 & 10.900 & 161.240 \\
\hline İçecek Gideri & 3.750 & 3.750 & 3.750 & 4.500 & 4.500 & 6.500 & 7.500 & 8.150 & 7.300 & 6.320 & 3.950 & 3.150 & 63.120 \\
\hline Çamaşırhane & 4.500 & 4.300 & 5.250 & 6.750 & 7.150 & 8.250 & 8.750 & 9.150 & 8.300 & 6.430 & 5.410 & 4.320 & 78.560 \\
\hline Mefruşat Gideri & 2.500 & 2.500 & 2.500 & 2.500 & 2.500 & 2.500 & 2.500 & 2.500 & 2.500 & 2.500 & 2.500 & 2.500 & 30.000 \\
\hline Pazarlama Gideri & 13.550 & 13.500 & 13.500 & 14.150 & 14.500 & 14.500 & 15.000 & 15.000 & 15.000 & 15.000 & 14.500 & 14.130 & 172.330 \\
\hline Temizlik Gideri & 1.750 & 1.750 & 1.750 & 1.750 & 1.750 & 1.750 & 1.750 & 1.750 & 1.750 & 1.750 & 1.750 & 1.750 & 21.000 \\
\hline Bakım-Onar. Gid. & 7.500 & 7.500 & 7.500 & 7.500 & 7.500 & 7.500 & 7.500 & 7.500 & 7.500 & 7.500 & 7.500 & 7.500 & 90.000 \\
\hline Enerji Gideri & 19.150 & 17.250 & 13.250 & 10.150 & 8.400 & 8.500 & 8.350 & 8.950 & 7.550 & 10.550 & 15.350 & 18.450 & 145.900 \\
\hline Haberleşme Gideri & 450 & 375 & 415 & 620 & 530 & 615 & 712 & 780 & 630 & 510 & 520 & 475 & 6.632 \\
\hline Amortisman & 28.590 & 28.590 & 28.590 & 28.590 & 28.590 & 28.590 & 28.590 & 28.590 & 28.590 & 28.590 & 28.590 & 28.590 & 343.080 \\
\hline Kurtasiye Gideri & 300 & 300 & 300 & 300 & 300 & 300 & 300 & 300 & 300 & 300 & 300 & 300 & 3.600 \\
\hline Diğer Giderler & 200 & 200 & 200 & 200 & 200 & 200 & 200 & 200 & 200 & 200 & 200 & 200 & 2.400 \\
\hline Toplam & 109.418 & 105.284 & 106.986 & 109.853 & 110.110 & 116.244 & 120.427 & 123.622 & 116.270 & 112.409 & 113.000 & 109.892 & 1.353 .515 \\
\hline
\end{tabular}


Gider kalemlerinin oluşturulmasında Gündoğmuş ve Köroğlu (2017)'nun çalışmasından yararlanılmış ve otel yetkilileri ile yapılan görüşmeler neticesinde söz konusu çalışmada sunulan gider kalemleri üzerinde mutabık olunmuştur.

\subsection{Stratejik Pazarlama Muhasebesi ile $\mathrm{X}$ Otel İşletmesinde Fiyatlandırma Kararları}

SPM, esasında genelde MBS özelde ise stratejik yönetim muhasebesiuygulamaları ile pazarlama kararlarını buluşturan bir kavramdır. SPM uygulanarak fiyatlandırma kararı verebilmek amaciyla bir takım analizlerin yapılması gerekmektedir.

Çalışmanın bu kısmında, X otel işletmesinde 2018 yılı için toplam gider fonksiyonu oluşturularak başabaş noktası analizi yapılacak, kar fonksiyonu oluşturularak 2018 yılı karı hesaplanacaktır. 2019 yılı fiyatlandırma kararları için, tahmini enflasyon rakamlarında hareketle 2019 y1lı giderleri tahmin edilecek, 2019 y1lı toplam gider fonksiyonu ortaya koyulacak ve amaçlanan kar için oda satış fiyatlarının ne olması gerektiği kararı tespit edilecektir.

\subsubsection{Maliyet-Hacim-Kar Analizi (2018 Yılı)}

Üretim hacmi ile giderler arasındaki ilişkilerden hareketle toplam gider fonksiyonunun oluşturularak sabit ve değişken giderlerin ortaya konulmasında farklı yöntemler bulunmaktadır. Ancak, objektifliği en yüksek olan yöntem "En Küçük Kareler Yöntemi (Doğrusal Regresyon Yöntemi)" olarak kabul edilmektedir (Büyükmirza, 2014:385). Yöntemde toplam gider fonksiyonunun $(\mathrm{TM}=\mathrm{ax}+\mathrm{b})$ unsurları olan birim değişken gider (a) ile toplam sabit gider (b)'in hesaplanması için iki farklı formülden yararlanılır. Bunlar;

$$
\begin{aligned}
& a=\frac{n \sum X Y-\left(\sum X\right)\left(\sum Y\right)}{n \sum X^{2}-\left(\sum X\right)^{2}} \\
& b=\frac{\sum Y-a\left(\sum X\right)}{n}
\end{aligned}
$$

Formüllerde bulunan " $\mathrm{X}$ " satılan yatak sayısını, "Y" toplam giderleri, "n" ay sayısını göstermektedir. Formüllerden hareketle 2018 y1lı toplam gider fonksiyonunun hesaplanması Tablo 3 ve devamında gösterilmiştir.

Tablo 3. En Küçük Kareler Yöntemi Hesaplama Adımları (2018 Y111)

\begin{tabular}{|l|c|c|c|c|}
\hline Aylar (a) & Satılan Yatak Sayısı (X) & Toplam Gider $(\mathbf{Y})$ & $\mathbf{X}^{\mathbf{2}}$ & $\mathbf{X Y}$ \\
\hline Ocak & 736 & 109.418 & 541.696 & 80.531 .648 \\
\hline Subat & 761 & 105.284 & 579.121 & 80.121 .124 \\
\hline Mart & 976 & 106.986 & 952.576 & 104.418 .336 \\
\hline Nisan & 1.229 & 109.853 & 1.510 .441 & 135.009 .337 \\
\hline Mayıs & 1.516 & 110.110 & 2.298 .256 & 166.926 .760 \\
\hline Haziran & 1.752 & 116.244 & 3.069 .504 & 203.659 .488 \\
\hline Temmuz & 1.842 & 120.427 & 3.392 .964 & 221.826 .534 \\
\hline
\end{tabular}




\begin{tabular}{|l|c|c|c|c|} 
Ağustos & 2.220 & 123.622 & 4.928 .400 & 274.440 .840 \\
\hline Eylül & 1.819 & 116.270 & 3.308 .761 & 211.495 .130 \\
\hline Ekim & 1.456 & 112.409 & 2.119 .936 & 163.667 .504 \\
\hline Kasım & 1.123 & 113.000 & 1.261 .129 & 126.899 .000 \\
\hline Aralık & 923 & 109.892 & 851.929 & 101.430 .316 \\
\hline $\mathrm{a}=12$ & $\sum \mathrm{X}=16.353$ & $\sum \mathrm{Y}=1.353 .515$ & $\sum \mathrm{X}^{2}=24.814 .713$ & $\sum \mathrm{XY}=1.870 .426 .017$ \\
\hline
\end{tabular}

$\mathrm{a}=((12 * 1.870 .426 .017)-(16.353 * 1.353 .515)) /\left((12 * 24.814 .713)-(16.353)^{2}\right)$

$\mathbf{a}=\mathbf{1 0 , 2 5}$ TL/Br. (Birim Değişken Gider)

$\mathrm{b}=(1.353 .515-(12 * 16.353)) / 12$

$\mathbf{b}=$ 98.825 TL/Ay (Aylık Toplam Sabit Gider)

Yıllık Toplam Sabit Gider $=98.825 * 12=1.185 .817$ TL. oluşturulmuştur.

Toplam Gider Fonksiyonu $_{(\text {Yıllık })}=10,25 \mathrm{X}+1.185 .817$ şeklinde

SPSS paket programı aracılığı ile yapılan doğrusal regresyon analizi neticesinde de aynı sonuçlara ulaşılmıştır. Hacimdeki değişimlerin giderleri etkileme düzeyini ifade eden determinasyon katsayısı $\left(\mathrm{r}^{2}\right)$ 0,798 fonksiyonun güvenilirliğini ifade eden $t$ değeri ise 6,663 olarak hesaplanmıştır. Determinasyon katsayısına göre giderlerdeki değişmenin \% 79,8'ini iş hacmi belirlemektedir. Hesaplanan $\mathrm{t}$ değeri, $\mathrm{n}=12$ örneklem büyüklüğ̈̈ ve $\% 95$ güven seviyesinde 2,228'den daha büyük olduğu için, elde edilen toplam gider fonksiyonunun güvenilirliğinin yüksek olduğu, bir başka ifade ile tesadüfi değil, gerçekte var olan bir gider hacim ilişkisini yansıttığını ortaya koymaktadır.

Burada dikkat edilmesi gereken husus, toplam gider fonksiyonunun yatak sayısı esaslı olarak oluşturulmasıdır. Farklı tip ve özelliklerdeki odalar esasında, aynı üretim döneminde, aynı üretim işlemleri neticesinde ortaya çıkan ve her biri başlı başına bir ana ürün olarak ifade edilen ortak (birleşik) ürünlerdir. Ortak (birleşik) ürünler ayrıldıkları üretim noktasına kadar yapılan giderleri birlikte yüklenirler. Giderler bu ürünler arasında bazı yöntemlere göre dağıtılırlar. Bu yöntemlerden birisi de katsayı yöntemidir (Akdoğan, 2009:414). Çalışmanın daha önceki kısımlarında açıklandığı üzere, otel işletmesinde odalar yatak sayısı esas alınarak katsayılandırılmıştır. Toplam gider fonksiyonu tek yatak için oluşturulmuştur. Katsayılar dikkate alındığında, birim değişken gider single oda için 10,25 TL, double oda için 20,50 TL $(10,25 * 2$ yatak $)$ ve süit oda için 30,75 TL $(10,25 * 3$ yatak $)$ olacaktır.

Otel işletmesinin toplam gelir fonksiyonu satışı yapılan oda fiyatlarının yıllık satış miktarı ile çarpılması sonucu elde edilecektir. İşletmenin muhasebe müdüründen alınan verilere göre 2018 yılında ortalama oda fiyatları şu şekilde gerçekleşmiştir:

- $\quad$ Single Oda Fiyatı (S) : 106,25 TL

- $\quad$ Double Oda Fiyatı (D) : 193,75 TL

- $\quad$ Süit Oda Fiyatı (SU) : 312,50 TL

$\mathrm{Bu}$ durumda, işletmenin toplam gelir fonksiyonu $\left(\mathrm{X}_{1}, \mathrm{X}_{2}\right.$ ve $\mathrm{X}_{3}$ her odanın satış hacmini göstermek üzere);

Toplam Gelir Fonksiyonu $=\mathrm{SX}_{1}+\mathrm{DX}_{2}+\mathrm{SUX}_{3}$ oluşturulmuştur.

Toplam Gelir Fonksiyonu $=106,25 X_{1}+193,75 X_{2}+312,5 X_{3}$ şeklinde 
Toplam gider ve toplam gelir fonksiyonlarının belirlenmesinden sonra otel işletmesinin 2018 faaliyet dönemi için kar fonksiyonu ortaya konulabilir. Birden fazla ürün olması durumunda kar, her bir ürünün birim katkı paylarının o üründen satılan ürün miktarı ile çarpılması, çarpımların toplanması ve sabit giderlerin bu toplamdan çıkarılması neticesinde bulunur (Büyükmirza, 2014:458).

$\operatorname{Kar}_{\mathbf{a}, \mathbf{b}, \ldots, \mathbf{n}}=\left(\left(\right.\right.$ Birim Satış Fiyatı ${ }_{\mathrm{a}}$-Birim Değişken Gider $\left._{\mathrm{a}}\right) *$ Satış Miktarı $\left._{\mathrm{a}}\right)+(($ Birim Satış Fiyatı ${ }_{b}$-Birim Değişken Gider $\left._{b}\right) *$ Satış Miktarı $\left._{\mathrm{b}}\right)+\ldots . .+\left(\left(\right.\right.$ Birim Satış Fiyat ${ }_{\mathrm{n}}$-Birim Değişken Gider ${ }_{n}$ )*Satış Miktarı ${ }_{n}$ ) - Toplam Sabit Gider

$\mathrm{Bu}$ durumda, $\mathrm{X}$ otel işletmesinin 2018 y1lı kar fonksiyonu şu şekildedir:

\subsection{5 .817}

$\operatorname{Kar}_{2018}=(106,25-10,25) * X_{1}+(193,75-20,50) * X_{2}+(312,5-30,75) * X_{3}-$

Oda satış rakamları yerine konulduğunda X Otel İşletmesinin 2018 yılı karı bulunacaktır.

- $\quad \operatorname{Kar}_{2018}=(96 * 6463)+(173,25 * 4900)+\left(281,75^{*} 30\right)-1.185 .817$

- $\quad$ Kar $_{2018}=\mathbf{2 9 1 . 9 2 8 , 5 0}$ TL olarak tespit edilmiştir.

Aynı sonuca ürünlerin satış içindeki paylarından hareketle tespit edilen ortalama katkı payı kullanılarak da ulaşılabilir. Özellikle, birden fazla ürünün üretildiği işletmelerde fiyatlama kararlarında ortalama katkı payındaki değişim üzerinden karar verildiğinden 2019 fiyat tahminlerine rehberlik etmesi için çalışmamızda işletmenin mevcut karı ortalama katkı payı üzerinden de hesaplanacaktır. Hesaplama adımları Tablo 4 ve devamında verilmiştir.

Tablo 4. Ortalama Katkı Payının Hesaplanması

\begin{tabular}{|l|c|c|c|c|c|c|}
\hline Oda Türü & $\begin{array}{c}\text { Oda Satıș } \\
\text { Miktarı } \\
\text { (Yıllı) }\end{array}$ & Oranı (\%) & $\begin{array}{c}\text { Ortalama Birim } \\
\text { Satı̧ Fiyatı }\end{array}$ & $\begin{array}{c}\text { Birim } \\
\text { Değişken Gider }\end{array}$ & $\begin{array}{c}\text { Birim } \\
\text { Katkı Payı }\end{array}$ & $\begin{array}{c}\text { Ortalama } \\
\text { Katkı Payı }\end{array}$ \\
\hline Single & 6463 & 0,567278 & 106,25 & 10,25 & 96 & 54,45870271 \\
\hline Double & 4900 & 0,430089 & 193,75 & 20,5 & 173,25 & 74,51285877 \\
\hline Suit & 30 & 0,002633 & 312,5 & 30,75 & 281,75 & 0,741902923 \\
\hline Toplam & 11393 & \multicolumn{7}{|c|}{ Ortalama Katkı Payı } & 129,7134644 \\
\hline
\end{tabular}

Ortalama katkı payından hareketle kar, ortalama katkı payının toplam satış miktarı ile çarpımı ve sabit giderlerin bundan çıkarılması ile bulunur (Hacırüstemoğlu vd. 1998:52).

Kar $_{\mathbf{a}, \mathbf{b}, . ., \mathbf{n}}=($ Ortalama Katkı Payı*Toplam Satış Miktarı $)-$ Toplam Sabit Gider

$\mathrm{Bu}$ durumda, ortalama katkı payından hareketle X Otel İşletmesinin 2018 yılı karı şöyle hesaplanacaktır:

- $\quad \operatorname{Kar}_{2018}=(129,7134644 * 11393)-1.185 .817$

- $\quad \operatorname{Kar}_{2018}=\mathbf{2 9 1 . 9 2 8 , 5 0}$ TL olarak tespit edilmiştir.

Hesaplamalardan da görüldüğü üzere her iki yöntem de aynı sonuca ulaşılmasını sağlamıştır. Karın ortalama katkı payından hareketle tespit edilmesi mamul karışımı olan işletmelerde amaçlanan kara ulaşmak için gerekli olan fiyatın belirlenmesinde önemli bir kolaylık sağlamaktadır. Bu nedenle, 2019 yılında, işletmenin amaçladığı kara ulaşabilmesi için belirlemesi gereken oda fiyatlarının ne kadar olacağının tespitinde bu yöntem kullanılacaktır. 


\subsubsection{Amaçlanan Kara Ulaşmada En Uygun Fiyatın Tespiti}

Buraya kadar yapılan analizler ile MBS'nin oluşturduğu bilgiler elde edilmiştir. 2019 yılında arzu edilen kara ulaşmak için gerekli olan fiyatın belirlenmesi hem MBS'yi hem de PBS 'yi ilgilendiren bir husustur. Dolayısıyla, çalışmanın bu kısmında SPM uygulaması olarak 2019 yılı için en uygun oda fiyatları tahmin edilecektir.

Otel yönetimi ile yapılan görüşmeler neticesinde yıllar itibarıyla oda satış rakamlarının benzerlik gösterdiği, 2019 yılında da önemli bir değişiklik olmasının beklenmediği anlaşılmıştır. Bu nedenle, 2019 yılında tahminlerde kolaylık sağlaması bakımından oda satış rakamlarının değişmeyeceği varsayılacaktır. Öte yandan, tahminlerin daha gerçekçi olabilmesi için giderlerde genel fiyat düzeyi artışlarına bağlı değişimler olacağı dikkate alınması gereken bir husustur. Bunu sağlamak amacıyla, tahmini enflasyon oranlarından hareketle 2019 yılı tahmini giderleri hesaplanacak, bu giderler üzerinden 2019 yılı kar fonksiyonu oluşturularak amaçlanan kara ulaşmak için en uygun oda fiyatları tespit edilecektir.

\section{- $\quad 2019$ Yılı Tahmini Giderlerinin Hesaplanması}

Türkiye Cumhuriyet Merkez Bankası (TCMB), aylar itibarı ile yayınladığı enflasyon raporlarında yıl sonu enflasyon oranı tahminlerine yer vermektedir. Çalışmanın yapıldı ğı tarihte yayınlanan en son enflasyon raporuna (TCMB, 2019:79) göre 2019 y1lı sonunda enflasyon oranının \% 14,6 olması beklenmektedir. 2019 yılında aylar itibarı ile enflasyon tahminlerinin ne olacağı söz konusu raporda açıkça ifade edilmemekle birlikte, raporda sunulan Enflasyon Tahmini Grafiğinden hareketle aylık enflasyon oranı tahminleri yaklaşık olarak belirlenebilir. Bu grafikten hareketle aylar itibarı ile 2019 yılı enflasyon oran tahminleri yaklaşık olarak Tablo 5'te sunulmuştur (TCMB, 2019:80).

Tablo 5. 2019 Y11 Tahmini Enflasyon Oranları

\begin{tabular}{|l|c|c|c|}
\hline Aylar & Enflasyon Oranı & Aylar & Enflasyon Oranı \\
\hline Ocak & 20,2 & Temmuz & 16,5 \\
\hline Şubat & 20 & Ağustos & 14 \\
\hline Mart & 19,7 & Eylül & 12,2 \\
\hline Nisan & 19,3 & Ekim & 13 \\
\hline Mayıs & 19 & Kasım & 14 \\
\hline Haziran & 18,7 & Aralık & 14,6 \\
\hline
\end{tabular}

Bu oranlara göre 2019 yılı giderlerine ilişkin tahmini rakamlar Tablo 6'da gösterildiği gibidir. 
Tablo 6. 2019 Y1l Tahmini Giderler

\begin{tabular}{|c|c|c|c|c|c|c|c|c|c|c|c|c|c|}
\hline Giderler Aylar & 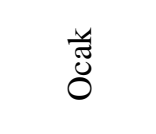 & $\begin{array}{l}\vec{\pi} \\
\stackrel{\Xi}{\Xi} \\
\text { W. }\end{array}$ & $\sum_{\Sigma}^{ \pm}$ & $\begin{array}{l}\text { च } \\
\stackrel{\text { Z }}{Z}\end{array}$ & $\sum_{i}^{\infty}$ & 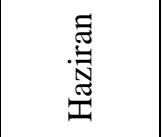 & 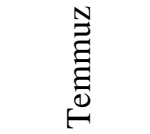 & $\underset{\substack{0 \\
0}}{\stackrel{0}{0}}$ & 昙 & $\frac{\Xi}{\square}$ & 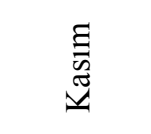 & 兰 & $\frac{\Xi}{\stackrel{\Xi}{\frac{\pi}{2}}}$ \\
\hline Personel Ücreti & 20287,36 & 18142,80 & 23199,06 & 25462,20 & 25811,10 & 25424,35 & 25775,63 & 25481,28 & 22832,70 & 20836,07 & 21580,20 & 20200,54 & 275033,28 \\
\hline Yiyecek Gideri & 12380,60 & 12180,00 & 12688,20 & 13719,50 & 14875,00 & 18540,94 & 19979,75 & 20976,00 & 18288,60 & 16181,60 & 15390,00 & 12491,40 & 187691,59 \\
\hline İçecek Gideri & 4507,50 & 4500,00 & 4488,75 & 5368,50 & 5355,00 & 7715,50 & 8737,50 & 9291,00 & 8190,60 & 7141,60 & 4503,00 & 3609,90 & 73408,85 \\
\hline Çamaşırhane & 5409,00 & 5160,00 & 6284,25 & 8052,75 & 8508,50 & 9792,75 & 10193,75 & 10431,00 & 9312,60 & 7265,90 & 6167,40 & 4950,72 & 91528,62 \\
\hline $\begin{array}{l}\text { Döşeme (Mefruşat) } \\
\text { Gideri }\end{array}$ & 3005,00 & 3000,00 & 2992,50 & 2982,50 & 2975,00 & 2967,50 & 2912,50 & 2850,00 & 2805,00 & 2825,00 & 2850,00 & 2865,00 & 35030,00 \\
\hline Pazarlama Gideri & 16287,10 & 16200,00 & 16159,50 & 16880,95 & 17255,00 & 17211,50 & 17475,00 & 17100,00 & 16830,00 & 16950,00 & 16530,00 & 16192,98 & 201072,03 \\
\hline Temizlik Gideri & 2103,50 & 2100,00 & 2094,75 & 2087,75 & 2082,50 & 2077,25 & 2038,75 & 1995,00 & 1963,50 & 1977,50 & 1995,00 & 2005,50 & 24521,00 \\
\hline Bakım-Onarım Gideri & 9015,00 & 9000,00 & 8977,50 & 8947,50 & 8925,00 & 8902,50 & 8737,50 & 8550,00 & 8415,00 & 8475,00 & 8550,00 & 8595,00 & 105090,00 \\
\hline $\begin{array}{l}\text { Elektrik-Su-Yakıt } \\
\text { Gideri }\end{array}$ & 23018,30 & 20700,00 & 15860,25 & 12108,95 & 9996,00 & 10089,50 & 9727,75 & 10203,00 & 8471,10 & 11921,50 & 17499,00 & 21143,70 & 170739,05 \\
\hline Telefon Gideri & 540,90 & 450,00 & 496,76 & 739,66 & 630,70 & 730,01 & 829,48 & 889,20 & 706,86 & 576,30 & 592,80 & 544,35 & 7727,01 \\
\hline Amortisman & 34365,18 & 34308,00 & 34222,23 & 34107,87 & 34022,10 & 33936,33 & 33307,35 & 32592,60 & 32077,98 & 32306,70 & 32592,60 & 32764,14 & 400603,08 \\
\hline Kırtasiye Gideri & 360,60 & 360,00 & 359,10 & 357,90 & 357,00 & 356,10 & 349,50 & 342,00 & 336,60 & 339,00 & 342,00 & 343,80 & 4203,60 \\
\hline Diğer Giderler & 240,40 & 240,00 & 239,40 & 238,60 & 238,00 & 237,40 & 233,00 & 228,00 & 224,40 & 226,00 & 228,00 & 229,20 & 2802,40 \\
\hline Toplam & $\begin{array}{l}131520,4 \\
4\end{array}$ & $\begin{array}{c}126340,8 \\
0\end{array}$ & $\begin{array}{c}128062,2 \\
4\end{array}$ & $\begin{array}{c}131054,6 \\
3\end{array}$ & $\begin{array}{c}131030,9 \\
0\end{array}$ & $\begin{array}{c}137981,6 \\
3\end{array}$ & $\begin{array}{c}140297,4 \\
6\end{array}$ & $\begin{array}{c}140929,0 \\
8\end{array}$ & $\begin{array}{c}130454,9 \\
4\end{array}$ & $\begin{array}{l}127022,1 \\
7\end{array}$ & $\begin{array}{c}128820,0 \\
0\end{array}$ & $\begin{array}{c}125936,2 \\
3\end{array}$ & $\begin{array}{c}1579450,5 \\
1\end{array}$ \\
\hline
\end{tabular}




\section{- 2019 Yılı Toplam Gider Fonksiyonunun Oluşturulması}

En küçük kareler yöntemi (doğrusal regresyon yöntemi) kullanılarak 2019 yılı toplam gider fonksiyonunun oluşturulmasına ilişkin hesaplamalar Tablo 7 ve devamında sunulmuştur.

Tablo 7. En Küçük Kareler Yöntemi Hesaplama Adımları (2019 Yılı)

\begin{tabular}{|l|c|c|c|c|}
\hline Aylar (a) & Satılan Yatak Sayısı (X) & Toplam Gider (Y) & $\mathbf{X}^{\mathbf{2}}$ & $\mathbf{X Y}$ \\
\hline Ocak & 736 & $131.520,44$ & $541.696,00$ & $96.799 .040,90$ \\
\hline Şubat & 761 & $126.340,80$ & $579.121,00$ & $96.145 .348,80$ \\
\hline Mart & 976 & $128.062,24$ & $952.576,00$ & $124.988 .748,19$ \\
\hline Nisan & 1.229 & $131.054,63$ & $1.510 .441,00$ & $161.066 .139,04$ \\
\hline Mayıs & 1.516 & $131.030,90$ & $2.298 .256,00$ & $198.642 .844,40$ \\
\hline Haziran & 1.752 & $137.981,63$ & $3.069 .504,00$ & $241.743 .812,26$ \\
\hline Temmuz & 1.842 & $140.297,46$ & $3.392 .964,00$ & $258.427 .912,11$ \\
\hline Ağustos & 2.220 & $140.929,08$ & $4.928 .400,00$ & $312.862 .557,60$ \\
\hline Eylül & 1.819 & $130.454,94$ & $3.308 .761,00$ & $237.297 .535,86$ \\
\hline Ekim & 1.456 & $127.022,17$ & $2.119 .936,00$ & $184.944 .279,52$ \\
\hline Kasım & 1.123 & $128.820,00$ & $1.261 .129,00$ & $144.664 .860,00$ \\
\hline Aralık & 923 & $125.936,23$ & $851.929,00$ & $116.239 .142,14$ \\
\hline a=12 & $\sum \mathrm{X}=16.353$ & $\sum \mathrm{Y}=1.579 .450,51$ & $\sum \mathrm{X}^{2}=24.814 .713$ & $\sum \mathrm{XY}=2.173 .822220,81$ \\
\hline
\end{tabular}

Yapılan hesaplamalar neticesinde 2019 yılı için toplam gider fonksiyonu;

- $\quad$ Toplam Gider Fonksiyonu (Ylltk $=\mathbf{8 , 5 0 X + 1 . 4 4 0 . 4 5 6}$ şeklinde oluşturulmuştur.

Mevcut oda satış fiyatları ile işletmenin toplam gelir fonksiyonu değişmeyecektir. Mevcut oda satış fiyatları ve toplam gelir fonksiyonu ile yeni toplam gider fonksiyonundan hareketle oluşturulan 2019 yılı kar fonksiyonu;

oluşacaktır.

$$
\operatorname{Kar}_{2019}=(106,25-8,50) * X_{1}+(193,75-17) * X_{2}+(312,5-25,5) * X_{3}-1.440 .456 \text { şeklinde }
$$

Mevcut oda satış rakamlarının aynı şekilde 2019 yılında da tekrarlanması durumunda kar;

- $\quad \operatorname{Kar}_{2019}=(97,75 * 6463)+(176,75 * 4900)+(287 * 30)-1.440 .456$

- $\quad \operatorname{Kar}_{2019}=65.987,25 \mathrm{TL}$ olarak gerçekleşecektir.

Birden fazla ürünün üretildiği işletmelerde kar fonksiyonun bu hali ile fiyatlandırma kararlarında kullanılması karmaşık bir çözümü gerektirmektedir. Çalışma konusu işletmede üç tip oda ve üç farklı fiyat söz konusu olacağı için kar fonksiyonu üç bilinmeyenli bir denklem halini alacaktır. Bundan dolayı, birden fazla mamul üreten işletmelerde amaçlanan kara ulaşmak için fiyat belirleme söz konusu olduğunda ortalama katkı payından hareketle oluşturulan kar fonksiyonu ve ortalama katkı payındaki değişim üzerinden karar vermek daha kolaydır. 2019 yılı verilerine göre işletmede üretilen ürünleri ortalama katkı payı Tablo 8'de hesaplanmıştır. 
Tablo 8. Ortalama Katkı Payının Hesaplanması (2019 yılı)

\begin{tabular}{|l|c|c|c|c|c|c|}
\hline Oda Türü & $\begin{array}{c}\text { Oda Satış } \\
\text { Miktarı } \\
\text { (Yıllık) }\end{array}$ & Oranı (\%) & $\begin{array}{c}\text { Ortalama Birim } \\
\text { Satış Fiyatı }\end{array}$ & $\begin{array}{c}\text { Birim } \\
\text { Değişken Gider }\end{array}$ & $\begin{array}{c}\text { Birim } \\
\text { Katkı Payı }\end{array}$ & $\begin{array}{c}\text { Ortalama } \\
\text { Katkı Payı }\end{array}$ \\
\hline Single & 6463 & 0,567278 & 106,25 & 8,50 & 97,75 & 55,45143948 \\
\hline Double & 4900 & 0,430089 & 193,75 & 17 & 176,75 & 76,01816905 \\
\hline Suit & 30 & 0,002633 & 312,50 & 25,50 & 287,00 & 0,755727201 \\
\hline Toplam & 11393 & \multicolumn{7}{|c|}{ Ortalama Katkı Payı } & 132,2253357 \\
\hline
\end{tabular}

Tablodan da görüldüğü üzere 2019 yılı ortalama katkı payı 132,2253357 olarak hesaplanmıştır. Ancak, bu rakam mevcut satış fiyatları için geçerlidir. X Otel İşletmesi, tahmini enflasyon oranını da dikkate alarak 2019 yılı karının bir önceki yıla göre \% 20 oranında artmasını hedeflemektedir. 2018 y1lı kar rakamı 291.928,50 TLolarak tespit edilmişti. Dolayısı ile, işletme 2019 yılında;

- $\quad$ Amaçlanan Kar $_{2019}=291.928,50 * 1,20=\mathbf{3 5 0 . 3 1 4 , 2 0}$ TLkar hedeflemektedir.

Ortalama katkı payı üzerinden kar fonksiyonu;

- $\quad \mathbf{K a r}_{\mathbf{a}, \mathbf{b}, . ., \mathbf{n}}=($ Ortalama Katkı Payı*Toplam Satış Miktarı $)-$ Toplam Sabit Gider şeklinde ifade edilmektedir.

$\mathrm{Bu}$ formül dikkate alındığında ve satış miktarının önceki yılla (2018) aynı olacağı varsayımından hareketle amaçlanan kara ulaşmada ortalama katkı payı;

Miktar

- Ortalama Katkı Payı= $($ Amaçlanan Kar + Toplam Sabit Gider $) /$ Toplam Satış

Formülü ile hesaplanacaktır. O halde; 2019 yılı amaçlanan kar düzeyinde ortalama katk1 pay1;

- $\quad$ Ort. Katkı Payı $=(350.314,20+1.440 .456) / 11393=157,1816203$ olacaktır.

$\mathrm{Bu}$ rakam tüm ürünler için geçerli olan toplam ortalama katkı payıdır. Her bir ürünün sağladığı ortalama katkı payını hesaplama için ortalama katkı payı artış katsayısı bulunmalıdır. Mevcut fiyatlar ile ortalama katkı payı 132,2253357 idi. Amaçlanan kara ulaşmak için ise ortalama katkı payının 157,1816203 olması gerekiyordu. Bu durumda;

- Ortalama Katkı Payı Artış Katsayısı= 157,1816203 / 132,2253357 = 1,188740565 olarak hesaplanır.

Artış katsayısının hesaplanmasıyla her bir ürünün sağladığı ortalama katkı payı ve her bir ürünün fiyatı ortaya konulabilir. Buna ilişkin hesaplamalar Tablo 9'da yapılmıştır.

Tablo 9. Amaçlanan Kara Ulaşmak İçin Fiyatlandırma Kararı

\begin{tabular}{|l|c|c|c|c|c|c|c|}
\hline & $\begin{array}{c}\text { Ortalama } \\
\text { Katkı Payı } \\
\text { Artış } \\
\text { Katsayısı }\end{array}$ & $\begin{array}{c}\text { Mevcut } \\
\text { Fiyatlarda } \\
\text { Ortalama } \\
\text { Katkı } \\
\text { Payları }\end{array}$ & $\begin{array}{c}\text { Amaçlanan } \\
\text { Kara } \\
\text { Ulaşmak Iç̧in } \\
\text { Yeni Ort. Katkı } \\
\text { Payları }\end{array}$ & $\begin{array}{c}\text { Satış } \\
\text { Içindeki } \\
\text { Pay (\%) }\end{array}$ & $\begin{array}{c}\text { Yeni Birim } \\
\text { Katkı } \\
\text { Payları }\end{array}$ & $\begin{array}{c}\text { Birim } \\
\text { Değişken } \\
\text { Gider }\end{array}$ & $\begin{array}{c}\text { Yeni Satış } \\
\text { Fiyatı }\end{array}$ \\
\hline & $\mathbf{( A )}$ & $\mathbf{( B )}$ & $(\mathbf{C}=\mathbf{A} * \mathbf{B})$ & $\mathbf{( D )}$ & $\mathbf{( E = ~ C / D )}$ & $(\mathbf{F})$ & $(\mathbf{E}+\mathbf{F})$ \\
\hline Single & 1,188740565 & 55,45143948 & 65,91737549 & 0,567278153 & 116,1993902 & 8,50 & $\mathbf{1 2 4 , 6 9 9 3 9 0 2}$ \\
\hline Double & 1,188740565 & 76,01816905 & 90,36588122 & 0,430088651 & 210,1098948 & 17,00 & $\mathbf{2 2 7 , 1 0 9 8 9 4 8}$ \\
\hline
\end{tabular}




\begin{tabular}{|l|c|c|c|c|c|c|c|} 
Suit & 1,188740565 & 0,755727201 & 0,89836358 & 0,002633196 & 341,1685421 & 25,50 & $\mathbf{3 6 6 , 6 6 8 5 4 2 1}$ \\
\hline Toplam & & 132,2253357 & 157,1816203 & & & & \\
\hline
\end{tabular}

Tablo 9'dan anlaşılacağı üzere, X Otel İşletmesinin 2019 yılında amaçladığı kara ulaşabilmesi için;

- $\quad$ Single oda fiyatını yaklaşık $125 \mathrm{TL}$,

- $\quad$ Double oda fiyatını yaklaşık 227 TL ve

- $\quad$ Süit oda fiyatını yaklaşık 365 TL olarak belirlemesi gerekmektedir.

Söz konusu fiyatlar 2019 yılında mamul satış karışımının değişmeyeceği varsayımı altında tahmin edilmiştir. Mamul satış karışımının değişmesi durumunda ortalama katkı payları da değişeceği için oda fiyatları farklılaşacaktır.

Tabloda tespit edilen oda fiyatları yuvarlanarak ifade edildiğinden söz konusu fiyatlar ile 2019 yılı tahmini karının ve kar artış oranının ne kadar olacağının yeniden tespit edilmesi yerinde olacaktır.

- $\quad \operatorname{Kar}_{2019}=((125-8,50) * 6463)+((227-17,00) * 4900)+((365-25,50 * 30)-1.440 .456$

- $\quad \operatorname{Kar}_{2019}=351.668,50$ TL olacaktır.

Muhasebe bilgi sisteminin maliyet-hacim-kar analizi neticesinde ortaya koyduğu tahmini fiyatlar pazarlama bilgi sisteminden elde edilen verilerle birleştirilerek fiyatlandırma karar süreçlerinde kullanılmalıdır. maliyet-hacim-kar analizleri nihai olarak geçmiş yıl verilerinden hareketle yapılan bir tahmini ifade etmektedir. İşletmeler, pazar araştırmalarından elde ettikleri talep tahmini, müşteri memnuniyeti vb. verileri kullanarak muhasebe bilgi sisteminin ortaya koyduğu tahmini fiyatların müşteriler tarafından kabul edilebilirliğini incelemelidir.

X Otel işletmesi, fiyatlandırma politikasını büyük ölçüde geçmiş yıl maliyetlerine, müşteri memnuniyetine ve rakiplerin fiyatlandırma politikalarınagörebelirlemektedir. Otel yönetimi ile yapılan görüşmelerde, müşterilerinin büyük çoğunlukla bölgede çeşitli firmalara bağlı olarak çalışan elemanlardan, transit seyahat eden yerli ve yabancı turistlerden oluştuğu belirlenmiştir. Otel, oda satışlarını perakende olarak yapabildiği gibi ulusal tur şirketleri üzerinde de gerçekleştirmektedir. Özellikle, sektörde itibar sahibi olan tur şirketleri üzerinden otelin satış yapıyor olması geçmiş yıllardaki fiyatlandırma politikasının kabul gördügünün göstergesidir. Otel işletmesi, fiyatlandırma politikasını büyük ölçüde, yukarıda ifade edilen hususları dikkate alarak oluşturmaktadır. Bunların dışında, otel işletmesinin pazarlama araştırması kapsamına girecek herhangi bir faaliyeti olmamıştır.

\section{SONUÇ}

İşletmelerde maliyet ve karlılık gibi stratejik öneme sahip konular söz konusu olduğunda, yöneticiler daima maliyetlerde minimizasyonu, karlılıkta ise maksimizasyonuamaçlamaya yönelik kararlar almayıtercihetmektedirler. İşletme yöneticileri bu amaçlara ulaşabilmek için işletmenin geleceği ile ilgili neredeyse bütün kararlarda muhasebe bilgi sisteminden elde edilen bilgileri kullanmaktadır. Ayrıca, işletme bilgi sisteminin tüm alt sistemleri de kendi içinde iletişim halinde ve işlevsel olarak çalışmalı ve yöneticilerin alacakları kararlara da hizmet etmelidir. 
İşletme yöneticilerinin işletmenin geleceğiyle ilgili olarak alacakları kararlar arasında yer alan, işletmelerin rekabet gücünü ve başarısını direkt olarak etkileyen konulardan biride fiyatlama politikasıdır. Fiyatlandırma kararları hem pazarlama bilgi sistemini hem de muhasebe bilgi sistemini ilgilendiren en önemli kararlardan birisidir. Gereğinden yüksek tespit edilecek bir fiyat, işletmenin pazar payını daraltabileceği gibi, gereğinden düşük tespit edilecek bir fiyat ise, işletmenin karlılığı ve sürekliliği üzerinde tehdit oluşturacaktır. Böyle önemli bir kararda pazarlama bilgi sistemi ile muhasebe bilgi sisteminin birlikte çalışması ve bu sistemlerden sağlanan bilgilerin doğruluğu ve güvenilirliği çok önemlidir. Stratejik pazarlama muhasebesi ise, bu iki sistemin arasındaki ilişki sonucu ortaya çıkan bir kavramdır. Stratejik pazarlama muhasebesi, esasında stratejik maliyet yönetiminin içerisinde ya da onunla sürekli etkileşimde bulunan bir yapıyı ifade etmektedir.

Stratejik pazarlama muhasebesi uygulaması ile Erzincan'da bulunan X Otel İşletmesinin maliyet yapısı ortaya konulmuş ve geçmiş yıl verileri bir takım varsayımlardan yararlanarak geleceğe yönelik fiyatlama tahmini yapılmıştır. Çalışmada öncelikle 2018 yılı maliyet verilerinden yararlanarak satışa sunulan ürünlerin ortalama katkı payından hareketle otel işletmesinin 2018 yılı kar fonksiyonu oluşturulmuş ve kar rakamı tespit edilmiştir. Daha sonra, 2019 y1lı tahmini enflasyon rakamlarından hareketle işletmenin maliyetleri güncellenmiştir. Bu veriler esas alınarak 2019 yılı amaçlanan karı ve bu kar rakamından yola çıkılarak ortalama katkı payındaki değişim katsayısından hareketle 2019 yılı oda satış fiyatları tahmin edilmiştir. Tahmin edilen ortalama satış fiyatları otel işletmesinin yapmış olduğu pazarlama araştırmaları çerçevesinde otel yönetimi ile birlikte değerlendirilmiştir. Geçmiş yıl verilerinden ve otel yöneticilerinin deneyimlerinden hareketle yapılan tespitlere göre mevcut enflasyon oranları ve maliyetler üzerinde etkisi olan diğer ekonomik koşullar göz önüne alındığında söz konusu fiyatların makul ve kabul edilebilir olduğu, pazar kaybına yol açmayacağı ifade edilebilir. Ancak, şunu da ifade etmek gerekir ki, daha sağlıklı sonuçlar elde edilebilmesi için işletmelerin daha detaylı pazarlama araştırmaları yapmaları elzemdir.

2018 yılında enflasyon oranlarında önceki yıllara kıyasla bir yükseliş ortaya çıkmıştır. Merkez Bankası Enflasyon Raporu'na göre 2019 yılında enflasyon oranlarında bir azalış beklenmekle birlikte önceki yıllara göre nispeten yüksek oranlar gözleneceği tahmin edilmektedir. Bu durum, işletmelerin maliyetlerinde de ciddi artışlara yol açabilir. Özellikle, çalışma konusu olan X Otel İşletmesi gibi yüksek sabit giderlerle çalışan işletmelerde enflasyon oranları neticesinde ciddi artış gösteren maliyetlerin karşılanarak enflasyon oranının üzerinde reel bir kar elde edebilmek için satış fiyatlarında da ciddi artışlar yapılması kaçınılmaz olacaktır. Nitekim, örnek işletmemizde de 2018 yılı fiyatları ile karşılaştırıldığında oda fiyatlarında ciddi artışlar yapılması gerekliliği ortadadır. Elbette, belirlenen fiyatların pazar araştırmaları ile de incelenmesi ve pazar payı kaybına yol açmayacak fiyatlar olduğunun teyit edilmesi gerekmektedir. Belirlenen fiyatların pazar payı kaybına yol açacağı tespitinin yapıldığı durumlarda amaçlanan karın daha düşük seviyelere çekilmesi ya da maliyetler üzerinde yapılacak yapısal çalışmalarla maliyetlerin düşürülmesi yoluna gidilmesi gerekecektir.

Stratejik pazarlama muhasebesi, yöneticilere maliyet ve fiyatlama hususunda alacakları kararlarla ilgili önemli bilgiler sağlayan bir stratejik maliyet yönetimi kavramı olarak ele alınabilir. Özellikle, fiyatlandırma kararlarının maliyet verilerinden çok deneyimlere göre belirlendiği bazı işletmelerde stratejik pazarlama muhasebesinin uygulama kolaylığı fiyatlandırma hususunda daha sağlıklı kararlar alınmasını sağlayabilir. Ulusal literatürde de bu yönde çalışmaların yapılması ve stratejik pazarlama muhasebesinin bir stratejik maliyet yönetimi unsuru olarak değerlendirilmesi söz konusu uygulamalardan yararlanacak işletmelere yol gösterici olabilir. 


\section{KAYNAKLAR}

Acar, D. - Özçelik, H. (2011), "Muhasebe Bilgi Kalitesini Etkileyen Kritik Başarı Faktörleri”, Muhasebe ve Finansman Dergisi, Sayı:49, ss.10-23.

Akdoğan, N. (1982), Pazarlama Maliyetleri ve Muhasebesi, Gazi ÜniversitesiAnkara İ.T.İ.A. Yayın No:197, Gazi Üniversitesi Basın-YayınYüksekokulu Basımevi,Ankara.

Akdoğan, N. (2009), Tekdüzen Muhasebe Sisteminde Maliyet Muhasebesi Uygulamaları, 8. Baskı, Gazi Kitabevi, Ankara.

Badem, C. - Fırat, D. (2011), "Temel Pazarlama Bileşenleri Açısından Muhasebe Verilerinin Kullanılması: Pazarlama Muhasebesi”, Kocaeli Üniversitesi Sosyal Bilimler Enstitüsü Dergisi, 1(21), ss.77-101.

Büyükmirza, K. (2014), Maliyet ve Yönetim Muhasebesi, Gazi Kitabevi, Ankara.

Ceran, Y. - Bezirci, M. (2011), "Pazarlama Bilgi Sistemi-Muhasebe Bilgi Sistemi İlişsisine Stratejik Bir Yaklaşım: Stratejik Pazarlama Muhasebesi”, Selçuk Üniversitesi Sosyal Bilimler Enstitüsü Dergisi, Sayı: 26, ss.103-115.

Ceran, Y. - İnal, M.E. (2004), "Maliyet Bilgileri Temeline Dayalı Pazarlama Kararları İçin Pazarlama Muhasebesi”, Erciyes Üniversitesi İ.İ.B.F. Dergisi, Sayı: 22, ss. 63-83.

Ceran, Y.- Özdemir, Ş. (2013), “Sağlık İşletmelerinde Paket İşlem Fiyat Uygulamasının Hedef Maliyetleme Yöntemi ve Stratejik Pazarlama Muhasebesi Açısından Değerlendirilmesi ve Özel X Diyaliz Merkezinde Bir Uygulama”, Sosyal Ekonomik Araştırmalar Dergisi, 13(26), ss.450-478.

Demireli, C. - Y1lmaz, M. (2013), “Zamana Dayalı Faaliyet Tabanlı Maliyetleme Yönteminin Stratejik Pazarlama Kararlarına Etkisi”, CBÜ Sosyal Bilimler Dergisi, 11(2), ss.294308.

Dinç, E. - Abdioğlu, H. (2009), "İşletmelerde Kurumsal Yönetim Anlayış1 ve Muhasebe Bilgi Sistemi İlişkisi; İMKB-100 Şirketleri Üzerine Ampirik Bir Araştırma", Balıkesir Üniversitesi Sosyal Bilimler Enstitüsü Dergisi, 12(21), ss.157-184

Dinçer B. - Dinçer, C. (2005), "Otel Yönetiminde Muhasebe Bilgi Sistemleri ve Pazarlama Kararları”, Review of Social, Economic\& Business Studies, 5(6), ss.353-365.

Doğan, M. (2016), "Kurumsal Yönetim ve Muhasebe Bilgi Sistemi İlişkisi”, Akademik Sosyal Araştırmalar Dergisi, 4(38), ss.194-201.

Gegez, E. (2015), Pazarlama Araştırmaları, Beta Kitabevi, İstanbul.

Gündoğmuş, E. - Köroğlu, Ç. (2017), "Pazarlama Bilgi Sistemi İle Muhasebe Bilgi Sistemi Arasındaki İlişkinin Stratejik Pazarlama Muhasebesi Açısından İncelenmesi: X Otel İşletmesinde Uygulama”, Muhasebe ve Denetime Bakış Dergisi, 50, ss. 1-20. 
Hacırüstemoğlu, R. - Sevgener, A. S. - Çakıcı, C. (1998), Yönetim Muhasebesi Uygulamaları, Alfa Yayinevi, İstanbul.

KelleyJr, T. C. (1966), “The Marketing-Accounting Partnership in Business”, TheJournal of Marketing, 30(3), pp.9-11.

Kırlı, M. - Gümüş, H. - Altıntop, M. (2012), "Stratejik Yönetim Muhasebesinin Tamamlayıcısı Olarak Stratejik Pazarlama Muhasebesi", 4. Uluslararası Balkanlarda Sosyal Bilimler Kongresi, Makedonya, ss.643-652.

Li, Eldon Y. (1997), "Marketing Information Systems in Small Companies", Information Resources Management Journal, 10(1), pp.27-35.

Mucuk, İ. (2007), Pazarlama İlkeleri, 16. Bask1, Türkmen Kitabevi, İstanbul.

Rese, M. (2006), “Marketing Accounting”,Handbuch Marketing-Controlling,2. Auflage, Ed; SvenReineckeandTorstenTomczak, Betriebswirtschaftlicher Verlag Dr. Th. GablerGWV FachverlageGmbH, Wiesbaden, pp. 741-766.

Sajady, H. - Dastgir, M. - Nejad, H. H. (2008), "Evaluation of theEffectiveness of Accounting Information Systems", International Journal of Information Science\&Technology, 6(2), pp.49-59.

Sevgener, A. S. - Hacırüstemoğlu R. (2000), Yönetim Muhasebesi, Alfa Yayınları, İstanbul

Sümerli Sarıül, S. (2018), "Pazarlama Muhasebesi ve Müşteri Kârlılık Yönetimine Yönelik Genel Bir Değerlendirme”,Uluslararası Yönetim Akademisi Dergisi,1(3), ss.425-435.

Şan, Ö. (1996), Genel İşletme, Anadolu Üniversitesi Yayınları, No:931, Eskişehir.

TCMB, Enflasyon Raporu, 2019-I, https://www.tcmb.gov.tr/wps/wcm/connect/cb440689938f-45e0-8cc2-f8700c7b677a/ki191.pdf?MOD=AJPERES\&CACHEID=ROOTWORKSPACE-cb440689-938f-45e08cc2-f8700c7b677a-mytN4Mp, (30.01.2019)

Tekin, V. N. (2006), Pazarlama İlkeleri (Politikalar-Stratejiler-Taktikler), Seçkin Yayıncılık, Ankara.

Temelli, F. - Eroğlu Pektaş, G. Ö.(2018), "Strategic Marketing Accounting in ProvidingSustainableCompetitiveSuperiority in GlobalizationProcess", Bingöl Üniversitesi Sosyal Bilimler Dergisi, 8(15), ss.1-15.

Tolon, M. (2006), "Pazarlama Bilgi Sisteminin Hizmet İşletmelerinin Uluslararasılaşmasındaki Önemi”, Üçüncü Sektör Kooperatifçilik, Sayı: 4, ss.26-41. 
Yıldız, A. - Ceran, Y. (2018), “Otel Yönetiminde Muhasebe Bilgi Sistemi ve Pazarlama Bilgi Sisteminden Yararlanılarak Stratejik Pazarlama Kararlarının Alınması; X Otel İşletmesinde Uygulama”, Bilge Uluslararası Sosyal Araştırmalar Dergisi, 2 (2), ss.112-129. 